\title{
ARAŞTIRMA / RESEARCH \\ Cardioprotective effect of all-trans retinoic acid on cisplatin induced cardiotoxicity in rats
}

Ratlarda cisplatin kaynaklı kardiyotoksisite üzerine all-trans retinoik asidin kardiyoprotektif etkisi

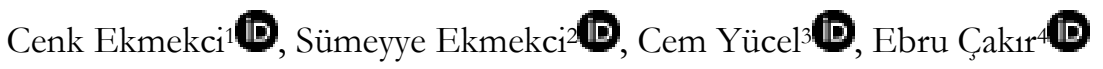

${ }^{1}$ Health Sciences University Tepecik Training and Research Hospital, Department of Cardiology, ${ }^{2}$ Department of Pathology, ${ }^{3}$ Department of Urology, Izmir, Turkey

${ }^{4}$ Katip Çelebi University, School of Medicine, Atatürk Training and Research Hospital, Department of Pathology, Izmir, Turkey

\begin{abstract}
Cukurova Medical Journal 2021;46(3):1230-1236.
Abstract

Purpose: Cisplatin (CP) is an antineoplastic agent widely used in the treatment of various tumors. Retinoic acid has potent antioxidant effects. In this study, it is aimed to reveal the effects of all-trans retinoic acid (ATRA) on CP induced cardiotoxicity.

Materials and Methods: In the study, wistar albino rat were used. Control group received single daily doses of 1 $\mathrm{ml} / \mathrm{kg}$ saline and ATRA group received single daily doses of $\operatorname{ATRA}(7,5 \mathrm{mg} / \mathrm{kg} /$ day) intraperitoneally (i.p.) for 10 days. ATRA+CP group received a single dose of $\mathrm{CP}(7 \mathrm{mg} / \mathrm{kg})$ i.p. on the fourth day of the 10 days of ATRA $(7,5 \mathrm{mg} / \mathrm{kg} /$ day) i.p. treatment. The rats in the CP group received only a single dose of cisplatin $(7 \mathrm{mg} / \mathrm{kg})$ i.p. given on the 4th of 10 days of treatment. After treatment, the groups were compared based on cardiac histopathology findings.

Results: Necrosis, cytoplasmic vacuolization, congestion, hemorrhage and edema were more common in the $\mathrm{CP}$ group than the control group). Necrosis and cytoplasmic vacuolization in the all-trans retinoic acid + cisplatin group was observed statistically significantly less frequently than the $\mathrm{CP}$ group.

Conclusion: This study confirmed that cisplatin therapy had destructive effects on heart tissue, and showed that alltrans retinoic acid treatment could histopathologically

Öz

Amaç: Cisplatin, pek çok farklı tümör tedavisinde kullanılan etkili bir antineoplastik ajandır. Retinoik asit güçlü antioksidan etkilere sahiptir. Bu çalıșmanın amacı, all-trans retinoik asidin (ATRA) cisplatin kaynaklı kardiyotoksisite üzerine etkilerini araştırmaktır.

Gereç ve Yöntem: Çalışmada wistar albino ratlar kullanıldı. Kontrol grubundaki ratlara 10 gün boyunca günlük $1 \mathrm{ml} / \mathrm{kg}$ salin intraperitoneal (i.p.) olarak verildi ve ATRA grubundaki ratlara 10 gün boyunca tek doz $(7,5$ $\mathrm{mg} / \mathrm{kg} /$ gün) ATRA i.p. verildi. ATRA + CP grubundaki ratlara 10 gün boyunca tek doz $(7,5 \mathrm{mg} / \mathrm{kg} /$ gün $)$ ATRA i.p. ve tedavinin dördüncü gününde tek doz CP $(7 \mathrm{mg} / \mathrm{kg})$ i.p. verildi. $\mathrm{CP}$ grubundaki ratlara ise 10 günlük tedavinin dördüncü gününde tek doz $\mathrm{CP}(7 \mathrm{mg} / \mathrm{kg})$ i.p. verildi. Tedaviden sonra gruplar kardiyak histopatoloji bulgularına göre karşılaştırıldı.

Bulgular: Nekroz, sitoplazmik vakuolizasyon, konjesyon, kanama ve ödem cisplatin grubunda kontrol grubuna göre daha yaygind. All-trans retinoik asid + cisplatin grubunda nekroz ve sitoplazmik vakuolizasyon, CP grubundan istatistiksel olarak anlamlı olarak daha az gözlendi.

Sonuç: $\mathrm{Bu}$ çalışma cisplatin tedavisinin kalp dokusu üzerinde yıkıcı etkileri olduğunu doğruladı ve all-trans retinoik asid tedavisinin histopatolojik olarak cisplatine bağlı kardiyotoksisiteyi önleyebildiğini gösterdi.
\end{abstract} prevent cisplatin-induced cardiotoxicity.

Keywords: Cisplatin, cardiotoxicity, retinoic acid, all-trans retinoic acid
Anahtar kelimeler: Cisplatin, kardiotoksisite, retinoik asid, all-trans retinoik asid

Yazışma Adresi/Address for Correspondence: Dr. Cenk Ekmekci, Health Sciences University Tepecik Training and Research Hospital, Department of Cardiology, Izmir, Turkey E-mail: cenkekmekci@yahoo.com

Geliș tarihi/Received: 16.03.2021 Kabul tarihi/Accepted: 17.07.2021 Cevrimiçi yayın/ Published online: 24.07.2021 


\section{INTRODUCTION}

Cisplatin [cis-diamminedichloroplatin (II)] (CP), is a DNA alkylating chemotherapeutic agent containing platinum and it is widely used in the treatment of various types of tumors involving head and neck, lung, bladder, testicle, cervix, and also lymphomas and childhood solid tumors ${ }^{1-3}$. It can cause serious side effects such as nephrotoxicity, ototoxicity and cardiovascular complications ${ }^{2-4}$.

There are limitations to the use of CP due to its acute and cumulative cardiotoxic effects ${ }^{2}$. The most common side effects include pericarditis, myocarditis, arrhythmia, hypertension, heart failure and rarely ones include coronary ischemia, heart tamponade and endomyocardial fibrosis ${ }^{1-2}$. It has been reported that natural antioxidants can protect cells against oxidative damage ${ }^{4}$. Among these, alltrans retinoic acid (ATRA) is a physiological metabolite of vitamin $\mathrm{A}$ and is the most common form of retinoid in nature ${ }^{5}$. ATRA can capture free radicals, prevent free radical formation and have cellular antioxidant effects without interfering with biological targets ${ }^{4}$. Since one of the mechanisms of cardiotoxic effect caused by CP is associated with oxidant injury, we propose that ATRA may reduce the cardiotoxicity of $\mathrm{CP}$ via it's antioxidant properties. Therefore, this study is aimed to show the histopathological findings of cardiotoxicity caused by the use of CP and to reveal the preventive effect of ATRA treatment against $\mathrm{CP}$-induced cardiotoxic damage.

Since CP induced cardiotoxicity is the main problem restricting the usage, there are plenty of published and continuing studies based on the toxic properties and the agents which may prevent the injury or reduce the damage in effected tissues. The presented study is one of few studies which is conducted on CP induced cardiotoxicity and the preventive effects of ATRA in an experimental rat model considering the detailed histopathology.

\section{MATERIALS AND METHODS}

\section{Study design}

The study is conducted after the ethical approval of Dokuz Eylul University (Ethical approval number: DEU/ HADYEK (Dokuz Eylül Üniversitesi Hayvan Deneyleri Yerel Etik Kurulu):47/2017) and all animal procedures were conducted in accordance with The
Guide for The Care and Use of Laboratory Animals of the Research Council. 270-320 g weighted Wistar albino rats were purchased from the animal laboratory of Dokuz Eylul University and they were kept in quarantine for 7 days before the study in the same conditions as study. During the study rats were kept in a room at $23-24{ }^{\circ} \mathrm{C}$ temperature and $50-55 \%$ humidity in 12-h dark and 12-h light cycles. The animals were fed with $8 \mathrm{~mm}$ sized pellet food and daily fresh tap water ad libitum. Twenty-eight rats were randomly divided into four groups as given below and the administrations were made in accordance with previous studies ${ }^{6-7}$.

1. Control group: Only a single daily dose of 1 $\mathrm{ml} / \mathrm{kg}$ saline injection intraperitoneally (IP) for 10 days.

2. ATRA group: Only a single daily dose of (7,5 $\mathrm{mg} / \mathrm{kg}$ IP) ATRA (Roche Diagnostics, Istanbul, Turkey) injection for 10 days.

3. ATRA+CP group: Combined ATRA $+\mathrm{CP}$ injection with a single dose of CP $(7 \mathrm{mg} / \mathrm{kg}$ IP) on the fourth day of 10-day ATRA treatment (7,5 mg/kg IP).

4. CP group: Only CP (Kocak Pharma, Istanbul, Turkey) injection with a single dose of CP (7 $\mathrm{mg} / \mathrm{kg} \mathrm{IP}$ ) on the fourth day of 10 days.

\section{Histopathology}

All animals were sacrificed using a high dose of ether on the 11th day after completing 10 days of the study period. The thoracic cavity of the rats was opened and their hearts were removed. Tissues were fixed in $10 \%$ buffered formalin and embedded in paraffin. Sections of four $\mu \mathrm{m}$ thickness of the cardiac tissue samples were stained with hematoxylin\&eosin (H\&E), and examined under light microscope (Olympus CX31, Tokyo, Japan). All samples were evaluated by 2 pathologists as for histopathological findings of cardiotoxicity. The histopathological findings such as congestion, hemorrhage, necrosis, presence of polymorphonuclear leukocytes (PNL), cytoplasmic vacuolization, edema were investigated. Congestion, hemorrhage and edema were divided into 3 subgroups as mild, moderate, and severe. Other parameters were grouped as present and absent.

\section{Statistical analysis}

The data analysis was performed using the Statistical Package for the Social Science (SPSS Inc., Chicago, Illinois, USA) version 24.0. The variables including 
congestion, hemorrhage and edema were analyzed by Kruskal Wallis test while differences between dual groups were assessed by Mann-Whitney U test. The statistical relation for categorical variables like necrosis, vacuolization and PNL was evaluated by performing Pearson chi-square test.

\section{RESULTS}

Histopathologically, necrosis; while it was seen in rats receiving $\mathrm{CP}$, it was not observed in the control and ATRA groups. There was a statistically significant difference between the control group and ATRA + CP $(p=0.023)$ and CP groups in terms of necrosis $(p<0.001)$. Necrosis was observed less frequently in the ATRA+CP group rather than in the CP group, with a statistically significant intergroup difference $(p=0.06)$. The difference between ATRA and ATRA $+\mathrm{CP}$ and $\mathrm{CP}$ groups was also statistically significant $(\mathrm{p}=0.023$ and $\mathrm{p}=0.001)$.

Cytoplasmic vacuolization was observed in the entire $\mathrm{CP}$ group, but not in the ATRA group. It was observed in only one rat in both the control and ATRA + CP groups. There was not any statistically significant difference between the control, ATRA, and ATRA + CP groups in terms of cytoplasmic vacuolization $(\mathrm{p}=0.900, \mathrm{p}=1.000)$, while a statistically significant difference existed between the control and CP groups $(p=0.006)$. A statistically significant difference was also observed between ATRA + CP and $\mathrm{CP}$ groups in terms of cytoplasmic vacuolization $(p=0.006)$. It was observed that congestion increased significantly in the CP group compared to the control and ATRA groups. In the ATRA + CP group, severity of congestion decreased. In terms of congestion, the difference between the control and the CP groups $(p=0.006)$, also between the ATRA and the CP groups $(\mathrm{p}=0.002)$ and the ATRA + CP group $(p=0.020)$ was statistically significant.

Hemorrhage was observed significantly more frequently in the CP group compared to the control and ATRA groups. There was a statistically significant difference in the severity of hemorrhage between the control and the CP groups $(p=0.002)$, between the ATRA group and the CP $(p=0.010)$ and the ATRA + CP groups $(\mathrm{p}=0.040)$.

While edema was not observed in the control and ATRA groups, edema was observed in all tissues in the CP and ATRA + CP groups. Edema was more severe in the CP group than the ATRA + CP group. In terms of edema, the difference between the control and the ATRA + CP groups $(p=0.006)$, between the ATRA and the CP groups $(\mathrm{p}=0.000)$ was statistically significant. The difference between the control and the CP groups in terms of edema was not statistically significant $(p=0.070)$. Histopathologically, polymorphonuclear leukocytes were seen in only one rat in the CP group.

When all groups were compared with each other, a significant relationship was detected between groups. Necrosis ( $p<0.001)$, vacuolization ( $p<0.001$ ), congestion $(\mathrm{p}=0.001)$, hemorrhage $(\mathrm{p}=0.001)$, edema $(\mathrm{p}=0.001)$ were statistically significant (Figure 1), while the presence of PNL was statistically insignificant $(\mathrm{p}=0.540)($ Table 1,2$)$.

Table 1. Results of comparing congestion, hemorrhage and edema between four groups

\begin{tabular}{|c|c|c|c|c|c|c|c|}
\hline & & \multicolumn{2}{|c|}{ Congestion } & \multicolumn{2}{|c|}{ Hemorrhage } & \multicolumn{2}{|c|}{ Edema } \\
\hline & $\mathrm{n}$ & Mean Rank & $\mathrm{p}$ & Mean Rank & $\mathrm{p}$ & $\begin{array}{l}\text { Mean } \\
\text { Rank }\end{array}$ & $\mathrm{p}$ \\
\hline Control & 7 & 9.93 & \multirow{4}{*}{0.001} & 9.93 & \multirow{4}{*}{0.001} & 9.29 & \multirow{4}{*}{0.001} \\
\hline ATRA & 7 & 7.36 & & 8.00 & & 7.50 & \\
\hline $\mathrm{CP}$ & 7 & 22.07 & & 22.43 & & 21.21 & \\
\hline CP+ATRA & 7 & 18.64 & & 17.64 & & 20.00 & \\
\hline
\end{tabular}

Kruskal-Wallis test. ATRA: All-Trans Retinoic Acid, CP: Cisplatin

Table 2. Results of comparing necrosis, vacuolization and PNL between four groups

\begin{tabular}{|c|c|c|c|c|c|c|c|c|c|}
\hline & \multicolumn{3}{|c|}{ Necrosis } & \multicolumn{3}{|c|}{ Vacuolization } & \multicolumn{3}{|c|}{ PNL } \\
\hline & $\mathrm{n}$ & $\%$ & $p$ & $\mathrm{n}$ & $\%$ & $p$ & $\mathrm{n}$ & $\%$ & $p$ \\
\hline Control & 0 & 0 & \multirow{4}{*}{$<0.001$} & 1 & 14.3 & \multirow{4}{*}{$<0.001$} & 1 & 14.3 & \multirow{4}{*}{0.54} \\
\hline ATRA & 0 & 0 & & 0 & 0 & & 0 & 0 & \\
\hline $\mathrm{CP}$ & 7 & 100 & & 7 & 100 & & 1 & 14.3 & \\
\hline $\mathrm{ATRA}+\mathrm{CP}$ & 4 & 57.1 & & 1 & 14.3 & & 0 & 0 & \\
\hline
\end{tabular}

Pearson Chi-Square test. PNL: polimorfonuclear leukocytes, ATRA: All-Trans Retinoic Acid, CP: Cisplatin 


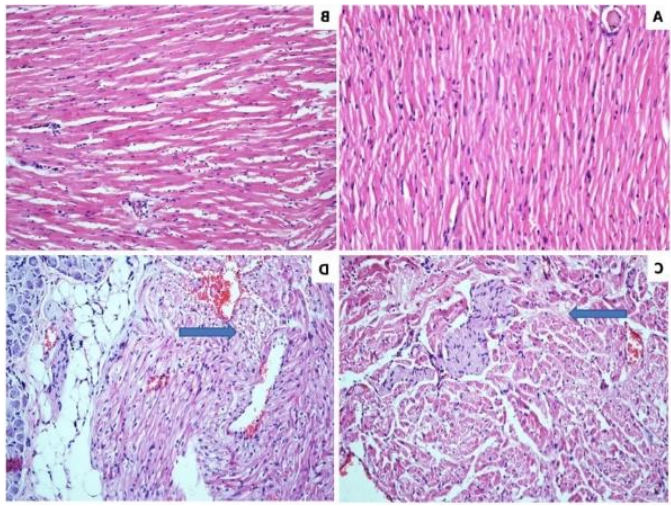

Figure 1. Control group with normal cardiac histology (H\&E, X200) (A),ATRA group showing mild edema (H\&E, X200) (B) CP group with extensive necrosis (arrow) and mild vacuolisation (H\&E, X200) (C), ATRA+CP group with mild vacuolisation and edema (arrow) (H\&E, X200) (D).

\section{DISCUSSION}

Although cardiotoxicity continues to be an important problem in anticancer treatment processes, cardioprotective strategies have been implemented against this problem. However, little success has been achieved in clinical approaches to improving cardiac toxicity caused by $\mathrm{CP}$; hence, it is necessary to develop a treatment to limit the side effects caused by $\mathrm{CP}^{8}$.

The clinical benefit of CP is particularly restricted due to its nephrotoxic and cardiotoxic negative effects, and mitigating such toxic effects by developing new agents remains the main goal. In the current study, the effects of cisplatin on cardiac tissue and potential amelioration of these effects with ATRA have been foreseen. CP treatment in rats leads to decreased glutathione levels and antioxidant enzyme activities in liver, heart, kidney, plasma ${ }^{9-13}$. On the other hand, cisplatin is reported to induce cardiac toxicity by increasing the production of reactive oxygen species $(\mathrm{ROS})^{11}$.

Treatment with CP disrupts the oxidant-antioxidant balance by leading an increase ROS production and suppressing the antioxidant enzyme activities. Cardiac tissue is extensively injured by these ROS. In addition, ROS production caused by $\mathrm{CP}$, induces release of cytochrome from mitochondria into cytoplasm and initiates the mitochondria- dependent pathway that causes apoptosis. It has been reported that lactate dehydrogenase leakage occurring after myocardial injury caused by production of ROS, increases cellular membrane permeability ${ }^{14}$. These changes reveals the critical role of oxidative injury in the formation of cardiotoxicity.

As a result of the complex events described above, myocardial damage occurs and manifests with different histopathological findings. Mitochondrial dysfunction, nuclear damage, activation of apoptotic pathways, and inflammation in the cardiac tissues is seen in CP associated cardiotoxicity ${ }^{10}$. In the literature, it has been reported that $\mathrm{CP}$ therapy causes varying degrees of degenerative changes in the form of disruption in muscle fibers in carsiad tissue, loss of cross stripes, distortion, absence of intercalated discs, apoptosis or necrosis of myocytes, and picnosis of nuclei. In addition to these findings, vacuolization and vascular enlargement have been described in the cytoplasms of muscle cells. Topal et al. ${ }^{15}$ showed that cisplatin caused hemorrhage, PNL infiltration, pycnotic nuclei, necrosis, edema and congestion. In accordance with these studies, we observed that necrosis, hemorrhage, congestion and vacuolization increased significantly in the cardiac tissues of rats that we applied CP.

In the previous studies, PNL cell infiltration has been shown to produce free radicals, which leads to lipid peroxidation followed by cellular necrosis ${ }^{16}$. It is also reported that oxidative stress caused PNL infiltration and edema in the heart tissue ${ }^{17}$. In our study, we observed PNL infiltration in one of the rats receiving $\mathrm{CP}$ and edema in all rats in the CP and CP + ATRA groups.

It has been reported that $\mathrm{NO}$ production in myocardial tissue increases in CP treatment and also it also enhances thrombogenesis by stimulating platelet accumulation and thromboxane formation ${ }^{12}$. During chemotherapy, CP-induced acute cardiovascular toxicity is thought to be caused by direct injury to the endothelial cells. Increased secretion of Von Willebrand factor by endothelium during chemotherapy has been described ${ }^{18}$. In one study histopathological examination of the heart tissues showed focal bleeding in the degenerated muscle bundles in the CP-treated group and severe obstruction in the vascular structures ${ }^{19}$. In our study, it was observed that vascular changes characterized with congestion and hemorrhage increased significantly in the group receiving cisplatin 
compared to the control and ATRA groups, with a statistically significant intergroup difference.

Till nowadays, various natural agents have been used in clinical studies and experimental models to assess whether they reduced CP-induced cardiotoxicity ${ }^{2}$. The use of natural antioxidants is a promising approach in this regard ${ }^{19}$. It is reported that natural antioxidants can protect cells against oxidative damage ${ }^{20}$.

Retinoids are molecules that are structurally related to retinol (vitamin A). They are involved in important physiological events such as cellular proliferation, differentiation, apoptosis, homeostasis, reproduction and fetal development ${ }^{5-21-22,23}$. Retinol is absorbed from the diet and stored in the liver as retinyl palmitate ${ }^{5}$. All-trans-retinoic acid (ATRA, tretinoin), 9-cis-RA, 13-cis-RA, isotretinoin) and retinal are physiological or synthetic derivatives of retinol ${ }^{8}$. Beta-carotene is used in the prevention and treatment of many diseases related with oxidative injury including cancer and cardiovascular diseases due to its free radical scavengering features. On the other hand, depending on the physiological environment, it can also act as a pro-oxidant that damages the tissue. In vitro studies have shown strong antioxidant activity of beta-carotene. Therefore, it is reported that it protects the biological systems against damage caused by CP.

In a study performed with cardiac tissue samples of mice, ATRA treatment was reported to be able to have a cardioprotective effect by preventing apoptosis and collagen accumulation in the presence of obesity and insulin resistance ${ }^{24}$. The results of the studies by Lou et al. ${ }^{21}$ have shown that ATRA protects the heart from $\mathrm{NiCl} 2$-induced cell apoptosis and tissue injury by reducing reactive oxygen species formation. In our study, in the ATRA + CP group, necrosis, which is the end point and irreversible step of cell damage, was seen statistically significantly less frequently than the CP group. Cytoplasmic vacuolization, which is an indicator of reversible damage and degeneration in the cell, was observed statistically significantly less frequently in the ATRA $+\mathrm{CP}$ group compared to the CP group. It is noteworthy that in the CP + ATRA group, cellular edema is less severe than that observed in the CP group. These results suggest that administration of ATRA to cisplatin- treated rats improves histopathological parameters associated with cardiac damage.
There are some other therapeutic agents which have documented cardioprotective effects on cisplatin induced cardiotoxicity such as $\mathrm{N}$-acetyl cysteine, taurine, coenzyme Q, trimetazidine and rutin ${ }^{13-17-18-25}$. Gunturk et al. ${ }^{25}$ investigated the effects of $\mathrm{N}$ acetylcysteine (NAC), which is an antioxidant, on cisplatin induced cardiotoxicity in a rat model and they showed that in the $\mathrm{CP}+\mathrm{NAC}$ group, interstitial edemaand vacuolization was at a significantly lower level than seen in the cisplatin group and hemorrhage was improved in the $\mathrm{CP}+\mathrm{NAC}$ group compared to the cisplatin only group, but was still high. While in the present study, edema was also more severe in the CP group than the ATRA + CP group but there was a statistically significant difference in the severity of hemorrhage between the ATRA group and the CP and the ATRA + CP groups. Topal et al. ${ }^{15}$ demonstrated the effect of rutin on $\mathrm{CP}$ induced cardiotoxicity in rats. In their study concucted in rats, continuous dilated congested vascular structures was found in the cardiac tissue in the $50 \mathrm{mg} / \mathrm{kg}$ rutin +5 $\mathrm{mg} / \mathrm{kg} \mathrm{CP}$ group and almost normal findings was observed in in the $100-\mathrm{mg} / \mathrm{kg}$ rutin $+5-\mathrm{mg} / \mathrm{kg} \mathrm{CP}$ group. In the present study congestion increased significantly in the CP group compared to the control and ATRA groups and also in the ATRA + CP group, the severity of congestion decreased. So vascular changes characterized with congestion and hemorrhage showed more evident improvement with ATRA when compared with other agents.

The presented study revealed the beneficial effects of ATRA histopathologically on CP induced cardiotoxicity however there are still limitations of the study. Biochemical enzymatic and ultrastructural analysis and small size of experimental and control groups are among the important limitations. The fact that the histomorphological results supported with both early and late period biochemical and enzymatic findings in cardiac damage, and also with changes in organelles as revealed by electron microscopic examinations at the ultrastructural level will provide better evaluation of the results.

Our study demonstrates the presence of histopathological findings associated with cardiac damage in rats receiving CP. In rats treated with ATRA, statistically significant results, suggesting improvements in histopathological findings seen in cardiac injury have been obtained. It will be appropriate to carry out controlled clinical studies where side effects of ATRA treatment such as frequently seen fever, headache, dry skin, bone pain and nausea-vomiting will be also considered. 
Yazar Katkıları: Calısma konsepti/Tasarımı: CE, SE, CY; Veri toplama: CE, SE; Veri analizi ve yorumlama: $\mathrm{CE}, \mathrm{SE}, \mathrm{CY}, \mathrm{EC}$; Yazı taslağ̀: CE, SE, EÇ; İçeriğin eleştirel incelenmesi: SE, EÇ; Son onay ve sorumluluk: CE, SE, CY. EÇ; Teknik ve malzeme desteği: CE, SE, CY, EÇ; Süpervizyon: CE, SE, CY; Fon sağlama (mevcut ise): yok.

Etik Onay: Bu çalısma için Dokuz Eylül Üniversitesi Hayvan Deneyleri Yerel Etik Kurulundan 04.09.2018 tarih ve 2017/47 sayll kararl ile etik onay alınmışıtır.

Hakem Değerlendirmesi: Dış bağımsız.

Çıkar Çatışması: Yazarlar çıkar çatışması beyan etmemişlerdir.

Finansal Destek: Yazarlar finansal destek bevan etmemislerdir.

Author Contributions: Concept/Design : CE, SE, CY; Data acquisition: CE, SE; Data analysis and interpretation: $\mathrm{CE}, \mathrm{SE}, \mathrm{CY}, \mathrm{EC}$ Drafting manuscript: CE, SE, EC ; Critical revision of manuscript: C SE, EC; Final approval and accountability: CE, SE, CY. EC; Technical or material support: CE, SE, CY. EC; Supervision: CE, SE, CY; Securing funding (if available): $\mathrm{n} / \mathrm{a}$

Ethical Approval: Ethical approval was obtained for this study from the Animal Experiments Local Ethics Committee of Dokuz Eylül University with the decision dated 04.09.2018 and numbered 2017/47.

Peer-review: Externally peer-reviewed.

Conflict of Interest: Authors declared no conflict of interest.

Financial Disclosure: Authors declared no financial support

\section{REFERENCES}

1. Smigic J, Sabo T, Vranic A, Zivkovic V, Srejovic I, Turnic TN, et al. Chronic effects of platinum (IV) complex and its diamine ligand on rat heart function: comparison with cisplatin. Mol Cell Biochem. 2019;458:89-98.

2. El-Hawwary AA, Omar NM. The influence of ginger administration on cisplatin-induced cardiotoxicity in rat: Light and electron microscopic study. Acta Histochemica. Acta Histochem. 2019;121:553-62.

3. Yago-Ibáñez J, García-Pastor C, Lucio-Cazaña FJ, Fernández-Martínez AB. Retinoic acid receptor-beta prevents cisplatin-induced proximal tubular cell death. Biochim Biophys Acta Mol Basis Dis. 2020;1866:165795.

4. Yucel C, Yucel EE, Arslan FD, Ekmekci S, Kisa E, Ulker $\mathrm{V}$, et al. All-trans retinoic acid prevents cisplatin-induced nephrotoxicity in rats. Naunyn Schmiedebergs Arch Pharmacol. 2019;392:159-64.

5. Özpolat B. Acute promyelocytic leukemia and differentiation therapy: molecular mechanisms of differentiation, retinoic acid resistance and novel treatments. Turk J Haematol. 2009;26:47-61.

6. Ewees MG, Abdelghany TM, Abdel-Aziz AA, AbdelBakky MS. All-trans retinoic acid mitigates methotrexate-induced liver injury in rats; relevance of retinoic acid signaling pathway. Naunyn Schmiedeberg's Arch Pharmacol. 2015;388:931-38.

7. Elsayed AM, Abdelghany TM, Akool el S, Abdel-Aziz AA, Abdel-Bakky MS. All-trans retinoic acid potentiates cisplatininduced kidney injury in rats: impact of retinoic acid signaling pathway. Naunyn Schmiedeberg's Arch Pharmacol. 2016;389:327-37.

8. Dugbartey GJ, Peppone LJ, de Graaf IA. An integrative view of cisplatin- induced renal and cardiac toxicities: Molecular mechanisms, current treatment challenges and potential protective measures. Toxicology. 2016;371:58-66.
9. Aktürk E, Kurtoğlu E, Harputluoğlu H. Cardiovascular Side Effects of Cancer Drugs: How to Identify, Treat, and Follow up These Side Effects İnönü Üniversitesi Tip Fakultesi Dergisi. 2011;18:13742.

10. Demir F, Narin F, Akgün H, Üzüm K, Saraymen R, Baykan A, et al. Effects of melatonin on experimental cardiotoxicity induced by doxorubicin. Çocuk Sağ Hast Derg. 2004;47:260-8.

11. Demkow U, Biatas-Chromiec B, StelmaszczykEmmel A, Radzikowska E, Wiatr E, RadwanRohrenschef $\mathrm{P}$ et al. The Cardiac Markers and Oxidative Stress Parameters in Advanced Non-Small Cell Lung Cancer Patients Receiving Cisplatin-Based Chemotherapy. EJIFCC. 2011;22:6-15.

12. Hideg K, Kálai T. Novel antioxidants in anthracycline cardiotoxicity. Cardiovasc Toxicol. 2007;7:160-4.

13. Al-Majed AA, Sayed-Ahmed MM, Al-Yahya AA, Aleisa AM, Al-Rejaie SS, Al-Shabanah OA. PropionylL-carnitine prevents the progression of cisplatininduced cardiomyopathy in a carnitine-depleted rat model. Pharmacol Res. 2006;53:278-86.

14. Viswanatha Swamy AH, Wangikar U, Koti BC et al. Cardioprotective effect of ascorbic acid on doxorubicin-induced myocardial toxicity in rats. Indian J Pharmacol. 2011;43:507-11.

15. Topal İ, Bilgin AÖ, Çimen FK, Kurt N, Süleyman Z, Bilgin $\mathrm{Y}$ et al. The effect of rutin on cisplatin-induced oxidative cardiac damage in rats. Anatol J Cardiol. 2018;20:136-42.

16. Sahna E, Deniz E, Aksulu HE. Myocardial ischemiareperfusion injury and melatonin. Anadolu Kardiyol Derg. 2006;6:163-8.

17. Tousson E, Hafez E, Zaki $S$ et al. The cardioprotective effects of $\mathrm{L}$-carnitine on rat cardiac injury, apoptosis, and oxidative stress caused by amethopterin. Environ Sci Pollut Res Int. 2016;23:20600-8.

18. Dieckmann KP, Struss WJ, Budde U. Evidence for acute vascular toxicity of cisplatin-based chemotherapy in patients with germ cell tumour. Anticancer Res. 2011;31:4501-5.

19. Soliman AF, Anees LM, Ibrahim DM. Cardioprotective effect of zingerone against oxidative stress, inflammation, and apoptosis induced by cisplatin or gamma radiation in rats. Naunyn Schmiedebergs Arch Pharmacol. 2018;391:819-32.

20. Ibrahim MA, Bakhaat GA, Tammam HG et al. Cardioprotective effect of green tea extract and vitamin $\mathrm{E}$ on Cisplatin-induced cardiotoxicity in mice: Toxicological, histological and immunohistochemical studies. Biomed Pharmacother. 2019;113:108731.

21. Lou S, Zhong L, Yang X, Xue T, Gai R, Zhu D et al. Efficacy of all-trans retinoid acid in preventing nickel induced cardiotoxicity in myocardial cells of rats. Food Chem Toxicol. 2013;51:251-8. 
22. Milani A, Basirnejad M, Shahbazi S, Bolhassani A Carotenoids biochemistry, pharmacology and treatment. Br J Pharmacol 2017;174:1290-324.

23. Raza S, Ullah K, Ahmed P, Khan B. Comparison of anthracycline-based combination chemotherapy with or without all-trans retinoic acid in acute promyelocytic leukemia. J Coll Physicians Surg Pak. 2008;18:546-50

24. Manolescu DC, Jankowski M, Danalache BA, Wang D, Broderick TL, Chiasson JL et al. All-trans retinoic acid stimulates gene expression of the cardioprotective natriuretic peptide system and prevents fibrosis and apoptosis in cardiomyocytes of obese ob/ob mice. Appl Physiol Nutr Metab. 2014;39:1127-36.

25. Gunturk EE, Yucel B, Gunturk I, Yazici C, Yay A, Kose $\mathrm{K}$. The effects of $\mathrm{N}$-acetylcysteine on cisplatin induced cardiotoxicity. Brat Med J. 2019;120:423-428. 